\title{
Molecular phylogenies support taxonomic revision of three species of Laurencia (Rhodomelaceae, Rhodophyta), with the description of a new genus
}

\author{
Florence ROUSSEAU ${ }^{1, *}$, Delphine GEY ${ }^{2}$, Akira KURIHARA ${ }^{3}$, \\ Christine A. MAGGS ${ }^{4}$, Julie MARTIN-LESCANNE ${ }^{5}$, Claude PAYRI ${ }^{6}$, \\ Bruno de REVIERS ${ }^{7}$, Alison R. SHERWOOD ${ }^{8}$ \& Line LE GALL ${ }^{9}$ \\ 1,7,9 Institut de Systématique, Evolution, Biodiversité (ISyEB), UMR 7205 CNRS, EPHE, MNHN, \\ UPMC, Sorbonne Universités, Equipe Exploration, Espèces, Evolution, Muséum National \\ d'Histoire Naturelle, case postale $N^{\circ} 39,57$ rue Cuvier, 75231 Cedex 05 Paris, France \\ ${ }^{2,5}$ Outils et Méthodes de la Systématique Intégrative, UMS 2700 MNHN, CNRS, \\ Service de Systématique Moléculaire, Muséum National d'Histoire Naturelle, \\ case postale $\mathrm{N}^{\circ} 26,57$ rue Cuvier, 75231 Cedex 05 Paris, France \\ ${ }^{3,8}$ Department of Botany, 3190 Maile Way, University of Hawaii, Honolulu, Hawaii, 96822 U.S.A. \\ ${ }^{4}$ Faculty of Science and Technology, Bournemouth University, Poole House, \\ Talbot Campus, Poole, Dorset BH12 5BB, U.K. \\ ${ }^{6}$ Institut de Recherche pour le Développement (IRD), UMR ENTROPIE-IRD, \\ UR, CNRS, BP A5, 98848 Noumea cedex, Noumea, New Caledonia \\ "Corresponding author E-mail: rousseau@mnhn.fr \\ ${ }^{2}$ Email: delphine.gey@mnhn.fr \\ 3,8 Email: asherwoo@hawaii.edu \\ ${ }^{4}$ Email: cmaggs@bournemouth.ac.uk \\ ${ }^{5}$ Email: Lescanne@mnhn.fr \\ ${ }^{6}$ Email: claude.payri@ird.fr \\ ${ }^{7}$ Email: reviers@mnhn.fr \\ ${ }^{9}$ Email: legall@mnhn.fr
}

\begin{abstract}
The systematics of the Laurencia complex was investigated using a taxon-rich data set including the chloroplast ribulose-1,5-bisphosphate carboxylase/oxygenase large subunit $(r b c \mathrm{~L})$ gene only and a character-rich data set combining mitochondrial cytochrome oxidase 1 (COI-5P), the $r b c \mathrm{~L}$ marker, and the nuclear large subunit of the ribosomal operon (LSU). Bayesian and ML analyses of these data sets showed that three species hitherto placed in the genus Laurencia J.V.Lamour. were not closely related to Laurencia s. str. Laurencia caspica Zinova \& Zaberzhinskaya was the sister group of the remaining Osmundea Stackh. species, L. crustiformans McDermid joined Palisada and L. flexilis Setch. consisted of an independent lineage. In light of these results a new genus, Ohelopapa F.Rousseau, Martin-Lescanne, Payri \& L.Le Gall gen. nov., is proposed to accommodate L. flexilis. This new genus is morphologically characterized by four pericentral cells in each vegetative axial segment; however, it lacks 'corps en cerise' in cortical cells and secondary pit connections between cortical cells, which are characteristic of Laurencia. Three novel combinations are proposed to render the classification
\end{abstract}


closer to a natural system: Ohelopapa flexilis (Setch.) F.Rousseau, Martin-Lescanne, Payri \& L.Le Gall comb. nov., Osmundea caspica (Zinova \& Zaberzhinskaya) Maggs \& L.M.McIvor comb. nov. and Palisada crustiformans (McDermid) A.R.Sherwood, A.Kurihara \& K.W.Nam comb. nov.

Keywords. Laurencia caspica, Laurencia crustiformans, Laurencia flexilis, Ohelopapa, Osmundea.

Rousseau F., Gey D., Kurihara A., Maggs C.A., Martin-Lescanne J., Payri C., Reviers B. de, Sherwood A.R. \& Le Gall L. 2017. Molecular phylogenies support taxonomic revision of three species of Laurencia (Rhodomelaceae, Rhodophyta), with the description of a new genus. European Journal of Taxonomy 269: 1-19. http://dx.doi. org/10.5852/ejt.2017.269

\section{Introduction}

The Laurencia complex consists of species which historically belonged to the genus Laurencia J.V.Lamour. (Rhodomelaceae, Ceramiales). Although it is easy to assign specimens to the Laurencia complex, it is far more difficult to delimit species and genera within the complex due to extensive morphological plasticity and the significance of inconspicuous anatomical characters.

Over the last two decades, the diversity within the genus Laurencia has been revealed by thorough morphological and molecular studies, leading to the recognition of distinctive anatomical features, as well as genetic divergences usually diagnostic at the generic level. The Laurencia complex has been split, leading to the resurrection or proposal of new genus names (Table 1). Currently, the Laurencia complex consists of seven genera: Chondrophycus (Tokida \& Y.Saito) Garbary \& J.T.Harper (Garbary \& Harper 1998), Coronaphycus Metti (Metti et al. 2015), Laurencia (Lamouroux 1813), Laurenciella V.Cassano, Gil-Rodríguez, Sentíes, Díaz-Larrea, M.C.Oliveira \& M.T.Fujii (Cassano et al. 2012), Osmundea Stackh. (Nam et al. 1994), Palisada K.W.Nam (Nam 2007) and Yuzurua (K.W.Nam) Martin-Lescanne (Martin-Lescanne et al. 2010). Despite the recognition of genera within the Laurencia complex, a limited number of species have been assigned to the four resurrected genera and the three recently described genera only include one (Laurenciella and Yuzurua) or two species (Coronaphycus) each (Table 1). Therefore, Laurencia s. str. is still by far the most speciose genus within the complex, and according to AlgaeBase (Guiry \& Guiry 2016) it currently accommodates 145 recognized species and 27 infraspecific taxa among no fewer than 421 taxa (Guiry \& Guiry 2016), strongly suggesting that steps toward taxonomic revision are necessary. Presently, most species of the genus Laurencia s. str. share the characters of four pericentral cells, trichoblastic spermatangia, tetrasporangial development from pericentral cells (Nam et al. 1994; Nam 1999), 'corps en cerise' (globular, hyaline bodies) in cortical cells and secondary pit connections between cortical cells. Reproductive characters are not always available, while the other anatomical features are difficult to observe, particularly in herbarium specimens. Consequently, the systematic revision of the Laurencia complex relies mostly on molecular databases to complete comprehensive phylogenetic analyses.

In the course of recent floristic surveys we have collected many specimens of the Laurencia complex from their type localities, including Laurencia flexilis Setch., L. caspica Zinova \& Zaberzhinskaya and L. crustiformans McDermid (e.g., Sherwood et al. 2010a, 2010b). These three species have character combinations that do not exactly match the description of Laurencia s. str. Laurencia flexilis has four pericentral cells, but unlike the type species of Laurencia, L. obtusa (Huds.) J.V.Lamour., it lacks secondary pit connections and 'corps en cerise', (Saito 1967, Masuda et al. 1999, 2006). Abe et al. (2006) resolved this taxon with moderate support as the earliest diverging lineage within the Laurencia complex in an $r b c \mathrm{~L}$ phylogeny. Regrettably, Abe's data are not publicly available and in the present study we generate novel sequences to address the question of the affinity of this taxon. Laurencia 
Table 1. Number of specific and infraspecific taxa currently recognized/total number of taxa, according to AlgaeBase (Guiry \& Guiry 2016), for each genus of the Laurencia complex.

\begin{tabular}{ccc}
\hline Genus & Authorship and publication & Current/total \\
\hline Chondrophycus & (Tokida \& Y.Saito) Garbary \& J.T.Harper (Garbary \& Harper 1998) & $17 / 41$ \\
Coronaphycus & Metti (Metti et al. 2015) & $2 / 2$ \\
Laurencia & J.V.Lamour., nom. cons. (Lamouroux 1813) & $172 / 421$ \\
Laurenciella & Cassano, Gil-Rodríguez, Sentíes, Díaz-Larrea, & $1 / 1$ \\
& M.C.Oliveira \& M.T.Fujii (Cassano et al. 2012) & \\
Osmundea & Stackh. (Stackhouse 1809) & $21 / 24$ \\
Palisada & K.W.Nam (Nam 2007) & $24 / 29$ \\
Yuzurua & (K.W.Nam) Martin-Lescanne (Martin-Lescanne et al. 2010) & $1 / 1$ \\
\hline Laurencia complex & & $\mathbf{2 3 8 / 5 1 9}$ \\
\hline
\end{tabular}

caspica, described from the Caspian Sea, likewise lacks secondary pit connections and 'corps en cerise' and has open spermatangial cups that resemble those of Osmundea hybrida (DC.) K.W.Nam from Atlantic Europe and O. maggsiana Serio, Cormaci \& G.Furnari from the Mediterranean Sea. Laurencia crustiformans, an unusual species that consists of a basal crust and nearly unbranched upright axes, was described from the Hawaiian Islands (McDermid 1989, Abbott 1999). It shares with Laurencia the presence of secondary pit connections between cortical cells and 'corps en cerise', but it differs by bearing tetrasporangia in a right-angle arrangement, as observed in species of Palisada and Yuzurua.

The aim of this manuscript is to assess the generic affinities of L. flexilis, L. caspica and L. crustiformans within the Laurencia complex by generating molecular data for specimens collected at the type localities of these three taxa, and inferring phylogenetic relationships from a character-rich combined dataset $(\mathrm{LSU}+r b c \mathrm{~L}+\mathrm{CO} 1)$ and a taxon-rich $r b c \mathrm{~L}$ only dataset.

\section{Material and methods}

\section{Specimen collection}

Newly sequenced specimens were collected in different localities around the world and are listed in Table 2, along with their valid names and GenBank accession numbers (NCBI GenBank) as well as the herbarium where the specimen was deposited. Samples were dried in silica gel or prepared as herbarium specimens and some of them were stored in 5\% buffered formalin in seawater. Specimens from the Hawaiian Islands were collected as part of the Hawaiian Rhodophyta Biodiversity Survey (Sherwood et al. 2010a, 2010b). During a monitoring project by Environment \& Resource Technology Limited (ERT Caspian) for BP Global in Sangachal Bay, Azerbaijan, Caspian Sea, in connection with existing and future operations at the Sangachal oil pipeline terminal (ERT Caspian 2002), the distribution of red algae was surveyed in June 2001 (by grab sampling) and 2002 (snorkeling). Laurencia caspica was collected at depths of 4-11 m, mostly more than $1 \mathrm{~km}$ from shore, on calcareous hard substrata and barnacle shells. The salinity in this area is 12-13 PSU, typical of the Caspian Sea (Lüning 1990: 123), and macroalgal diversity is very low, with only six red algal species recorded (ERT Caspian 2002) from the 30 species known from the Caspian (Lüning 1990). For molecular investigation, macroalgal samples were collected by van Veen grab at one station in the bay in September 2003. Specimens from New Caledonia were collected as part of the New Caledonia coral reef biodiversity survey in 2003, 2005 (BSM-LOYAUTE Alis Vessel campaign and BIODIP Alis Vessel campaign) and 2008. The specimen of L. flexilis was collected at the type locality in Tahiti, French Polynesia, in 2007 and deposited at UPF (Université de Polynésie Française). Acronyms of herbaria follow Thiers (continuously updated). 


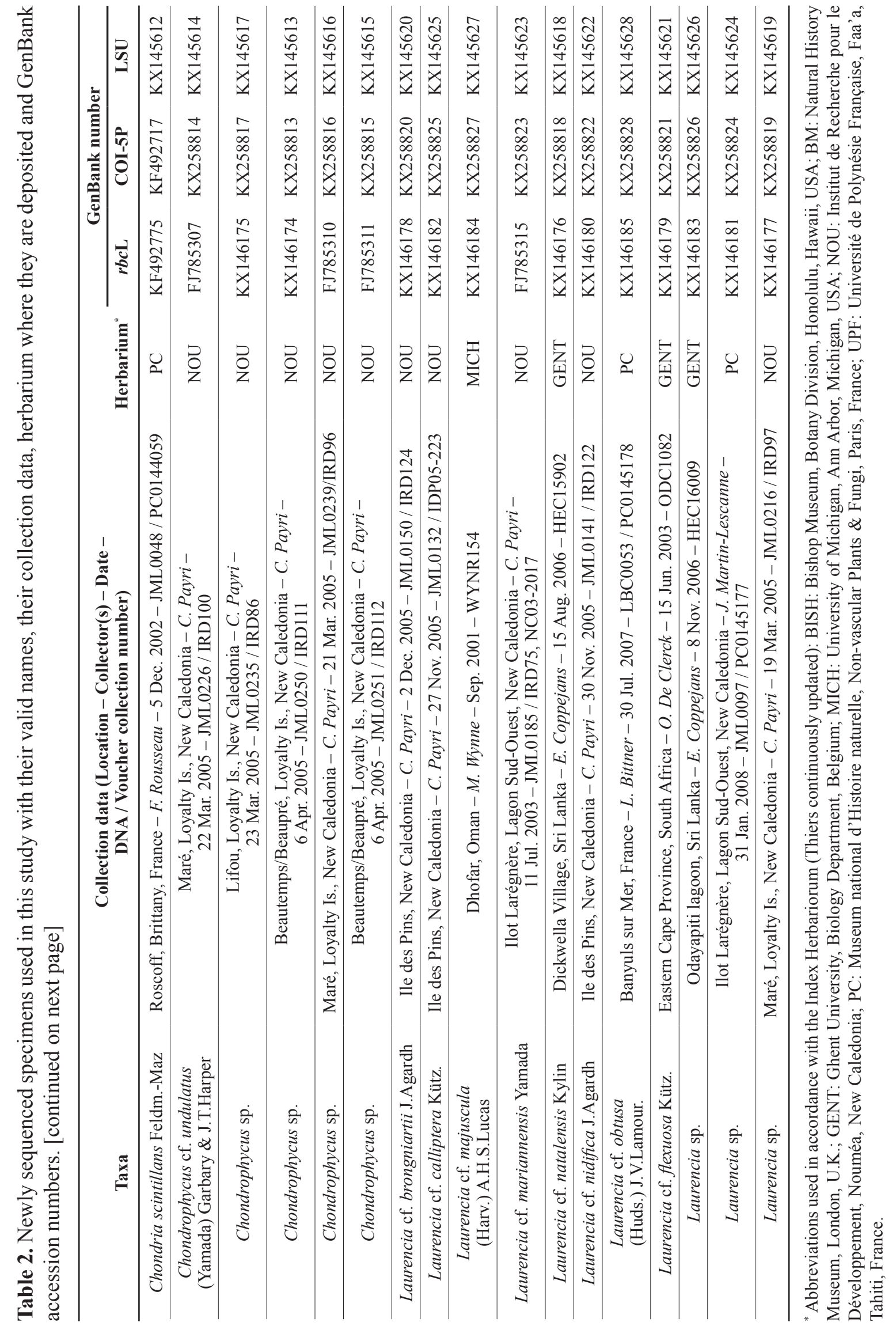




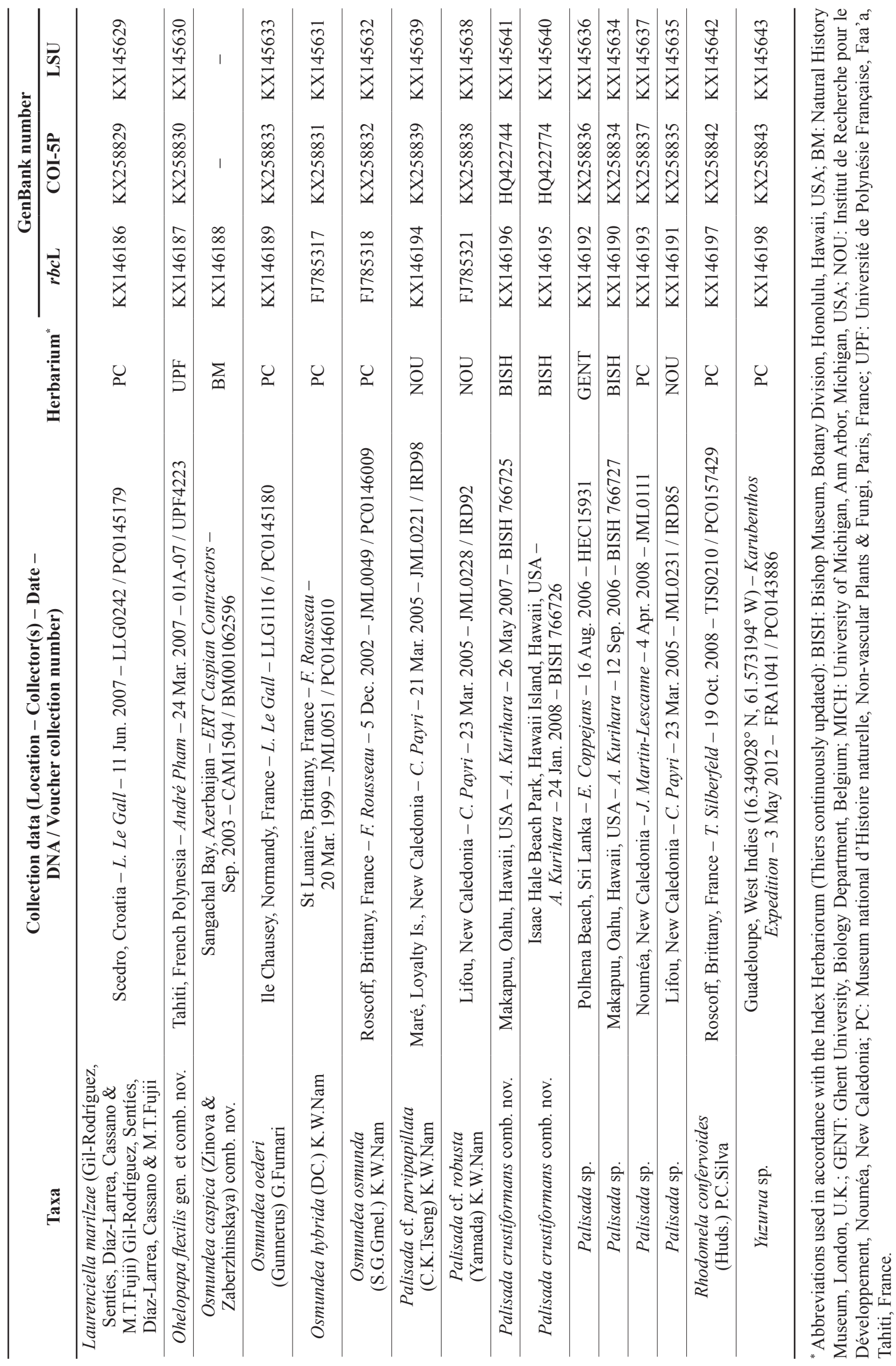




\section{Sample preparation for anatomical studies}

Morphology was observed under dissecting and compound microscopes and permanent slides were made from sections stained with acidified aniline blue stain (4\% in seawater) and mounted in $50 \%$ dilute Karo corn syrup.

\section{Extraction, amplification and sequencing}

Total cellular DNA was extracted from tissues preserved in silica gel and dry herbarium specimens using the DNeasy Plant Mini Kit (QIAGEN, Valencia, California, USA or Qiagen GmbH, Hilden, Germany). From $0.5 \times 10^{-3}$ to $10^{-3} \mathrm{mg}$ of proteinase $\mathrm{K}$ was added to the lysis buffer to improve the DNA yield. Except for $L$. caspica, the $r b c \mathrm{~L}$ coding region ( $1467 \mathrm{bp}$ ) was amplified using the following combinations of primers: F- $r b c \mathrm{~L}$ start $\times \mathrm{R}-753$ (Freshwater \& Rueness 1994) for the 5' end, $r b c \mathrm{LFC} \times 1011 \mathrm{R}$ (Nam \& Choi 2000) or F-577 $\times$ R1381 (Freshwater \& Rueness 1994) for the middle fragment and F-993 $\times$ R-rbcS start (Freshwater \& Rueness, 1994) for the 3' end. The protocol used for PCR amplifications was presented in Martin-Lescanne et al. (2010).

For L. caspica, PCR amplification used a PTC-200 DNA Engine (MJ Research Inc.). All PCR amplifications were carried out using the published primers $r b c$ LFC as the forward primer and $r b c$ LRD as the reverse primer (Nam et al. 2000), and all reactions contained $200 \mu \mathrm{M}$ each of dATP, dCTP, dGTP and dTTP, $0.3 \mu \mathrm{M}$ of each primer, $2.5 \mathrm{mM} \mathrm{MgCl}_{2}$ and 1.6 units of Taq polymerase (Bioline). The PCR cycle used was as previously indicated (Nam et al. 2000). The mitochondrial marker cytochrome oxidase subunit 1 (CO1) was amplified using the primer pair GAZF1 and GAZR5 with the PCR conditions of Saunders (2005) and Clayden \& Saunders (2014). LSU was amplified as three overlapping fragments using primers T01N/T20, T04/T08 and T05/T15, and using the PCR primers and the internal primers T10, T16N, T19N, T22, T24, T25, T30 and T33, following the protocols of Harper \& Saunders (2001) and Le Gall \& Saunders (2010).

The resulting PCR products were purified and used as templates for cycle sequencing reactions with the same primers as those used for the initial amplifications. These steps were performed by Genoscope (www.genoscope.fr, Evry, France) or Eurofins (France). For L. caspica, PCR fragments were purified using the High Pure PCR Product Purification Kit (Roche Diagnostics Ltd., Lewes, UK), according to the manufacturer's instructions. The PCR products were then directly sequenced commercially by MWG-Biotech, Ebersberg, Germany.

\section{Sequence alignments and phylogenetic analyses}

Sequences were obtained for both DNA strands, assembled and corrected using Sequencher ${ }^{\mathrm{TM}}$ v. 4.1 (Gene Codes Corporation, Ann Arbor, Michigan) or Codoncode (Dedham, Massachusetts). Alignments of LSU, $r b c \mathrm{~L}$ and CO1 were performed with MEGA v. 6 (Tamura et al. 2013). The LSU alignment was adjusted by eye with the objective of minimizing gaps, and four ambiguous regions corresponding to $109 \mathrm{nt}$ were excluded before phylogenetic analyses.

Two datasets were analysed. The first one included 32 taxa for which COI-5P, $r b c \mathrm{~L}$ and LSU (3 genes) were generated (giving $4801 \mathrm{nt}$ alignment length) and a second one was based on only $r b c \mathrm{~L}$ sequences (1395 nt) for 117 taxa. For the $r b c \mathrm{~L}$ dataset, a global alignment (198 taxa) was generated with all GenBank sequences belonging to the Laurencia complex and with our newly produced sequences. We then screened the 198 sequences, of which we finally selected 117 . We excluded sequences that were too short (less than $900 \mathrm{nt}$ ) and conserved only sequences that diverged by more than $2 \mathrm{nt}$ (collapsetypes.pl available at http://sourceforge.net/projects/collapsetypes/). Finally, rapid NJ analyses were performed separately on sub-alignments corresponding to typical PCR primer amplifications (0-527, 528-701, 702 1099 and 1100-1395) to reveal a putative conflict signal. The selection of sequences is explained in the Supplementary file. 


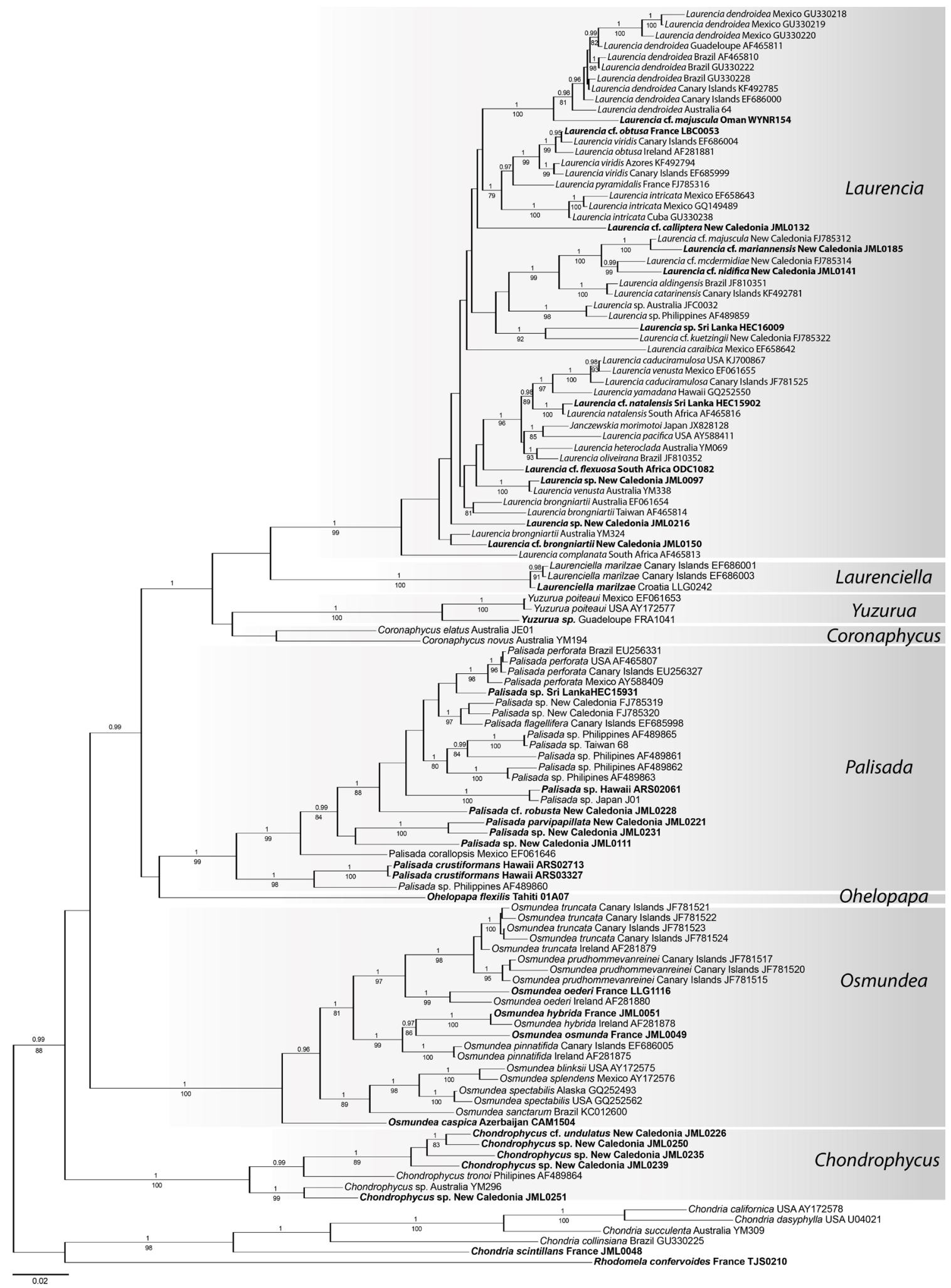

Fig. 1. Tree inferred from $r b c \mathrm{~L}$ using Bayesian analysis (BI) and including 111 specimens of members of the Laurencia complex and six outgroup taxa. The numbers above branches indicate Bayesian posterior probabilities (pp) and below branches indicate bootstrap values (bp) inferred from 1000 ML bootstrap replicates (ML); $\mathrm{pp}<0.95$ and $\mathrm{bp}<75 \%$ are not shown. Taxa for which new sequences were produced are indicated in bold. 


\title{
Phylogenetic analyses
}

Bayesian and ML analyses were performed using MrBayes v. 3.2.6 (Ronquist et al. 2012) and RAxML v. 8.2.0 (Stamatakis 2014) on the cipres portal. For both BI and ML analyses, the $r b c \mathrm{~L}$ data set was partitioned by codon position ( $1+2$ vs 3 ) while the three-gene data set was analysed in five partitions by gene and codon positions (codon position 1 and 2 merged into one partition). BI analyses were run with GTR $+\mathrm{I}+\mathrm{G}$ model parameters estimated independently for each partition, with four heated Monte Carlo Markov Chains for $10^{7}$ generations, with sampling intervals of 1000 generations, to produce 10000 trees. Nodal support was assessed by calculating posterior probability (PP) values at each node of the resulting consensus tree after a burn-in of $10 \%$ of the trees. The ML analyses were conducted with a GTRGAMMA model with ML estimates of base frequencies. The best-scoring ML tree and 1000 bootstrap trees were obtained using the rapid hill-climbing algorithm (-f a option).

\section{Results}

The $r b c \mathrm{~L}$ only dataset (Fig. 1) and the combined dataset including CO1, $r b c \mathrm{~L}$, and LSU (Fig. 2) were analysed using ML and Bayesian approaches to delimit genera within the Laurencia complex and to assess phylogenetic relationships among genera. The two trees (Figs 1-2) were congruent in delimiting strongly supported lineages which overall correspond to the genera currently recognized in the Laurencia complex, with a few exceptions. Laurencia caspica was resolved as a sister taxon to all the species of Osmundea included in these analyses. Laurencia crustiformans allied with species of Palisada with strong (Fig. 1) to full support (Figs 1-2). Laurencia flexilis did not join the remaining species of Laurencia and its position varied in the tree depending on the analyses. It was resolved as sister to either Yuzurua (Fig. 2) or Palisada (Fig. 1). Moreover, our analyses revealed that a specimen collected in the Mediterranean Sea grouped with the recently described genus Laurenciella with a divergence from the generitype from the Canary Islands of only $0.5 \%$. In addition, the monotypic genus Yuzurua encompassed two lineages with a divergence of $4.7 \%$ : one corresponded to a group of specimens from the Caribbean region and the second to a specimen from Guadeloupe. Intergeneric relationships were not supported by either reconstruction method in our taxon-rich dataset (Fig. 1) or in our character-rich dataset (Fig. 2).

\author{
Phylum Rhodophyta Wettst. (von Wettstein 1901) \\ Subphylum Eurhodophytina G.W.Saunders \& Hommers. (Saunders \& Hommersand 2004) \\ Class Florideophyceae Cronquist (Cronquist 1960) \\ Subclass Rhodymeniophycidae G.W.Saunders \& Hommers. (Saunders \& Hommersand 2004) \\ Order Ceramiales Oltm. (Oltmanns 1904) \\ Family Rhodomelaceae Aresch. (Areschoug 1847)
}

Genus Ohelopapa F.Rousseau, Martin-Lescanne, Payri \& L.Le Gall gen. nov.

Fig. 3; Table 2

\section{English diagnosis}

With the characters of the genus Laurencia such as four pericentral cells, but lacking secondary pit connections between cortical cells and 'corps en cerise' inclusions in cortical cells.

\section{Etymology}

Ohelopapa means "strawberry" in Tahitian, an allusion to the Tahitian origin, the red color, and the many stolons developed by Ohelopapa flexilis.

\section{Type species}

Ohelopapa flexilis (Setch.) F.Rousseau, Martin-Lescanne, Payri \& L.Le Gall comb. nov. Sole species presently included in the genus. 
Ohelopapa flexilis (Setch.) F.Rousseau, Martin-Lescanne, Payri \& L.Le Gall comb. nov.

Fig. 3; Table 2

\section{Basionym}

Laurencia flexilis Setch., University of California Publications in Botany 12: 101, pl. 19, figs 1-6 (Setchell 1926) (in Tahitian algae collected by Setchell W.A., Setchell C.B. \& Parks H.E., 1926).

\section{Type material}

\section{Holotype}

FRANCE: French Polynesia, Tahiti, UC261333 deposited at the Jepson Herbaria (JEPS, University of California, Berkeley).

Original material is also preserved in SAP fide Masuda et al. $(1999,2006)$.

\section{Type locality}

Reef at Tahara Mountain, Tahiti.

\section{Other material examined}

FRANCE: French Polynesia, Tahiti, reef at Tahara Mountain [type locality], 24. Mar. 2007, André Pham 01A-07/UPF4223 (UPF).

\section{Distribution}

Tropical regions in the Pacific (Setchell 1926; Cribb 1983; Masuda et al. 1999), in the Indian Ocean (Silva et al. 1996) and on coasts of Japan (Masuda et al. 2006).

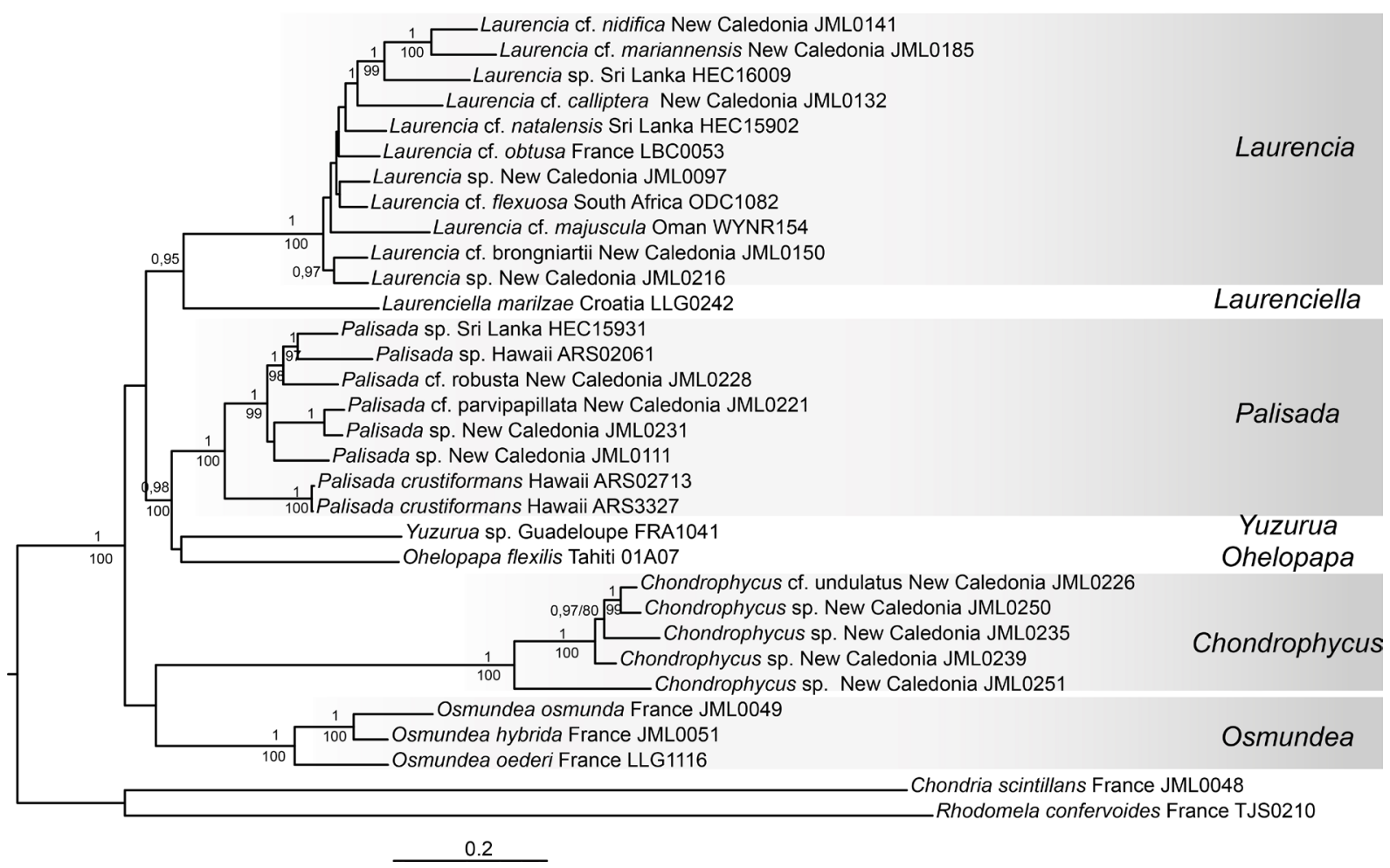

Fig. 2. Tree inferred from COI-5P $+r b c \mathrm{~L}+\mathrm{LSU}$ using Bayesian analysis (BI) and including 30 specimens of the Laurencia complex and two outgroup taxa. The numbers above branches indicate Bayesian posterior probabilities (pp) and below branches indicate bootstrap values (bp) inferred from $1000 \mathrm{ML}$ bootstrap replicates (ML); $\mathrm{pp}<0.95$ and $\mathrm{bp}<75 \%$ are not shown. 


\section{Remarks}

Ohelopapa flexilis (Fig. 3A) specimens included in this study matched previous descriptions where anatomical features were thoroughly illustrated (Setchell 1926; Masuda et al. 1999, 2006). Notably, we observed, in the outermost cortical layer, translucent cells without secondary pit connections, whereas the inner cortical layer (just below this) consisted of pigmented cells with secondary pit connections (Fig. 3B). This anatomical character was highlighted by Fujii \& Cordeiro-Marino (1996) for C. translucidus (M.T.Fujii \& Cord.-Mar.) Garbary \& J.T.Harper. Based on molecular data, Fujii et al. (2006) showed that C. translucidus pertains to genus Laurencia rather than to Chondrophycus. Interestingly, Masuda et al. (2006) used the absence of secondary pit connections between superficial cortical cells as a new argument to support the distinction between L. flexilis and another morphologically similar species, L. tropica Yamada. It would be interesting in the future to test with molecular characters whether L. tropica belongs to the genus Ohelopapa and also to analyse the taxonomic significance of the presence of an outermost cortical layer formed of translucent cells without secondary pit connections.

\section{Genus Palisada K.W.Nam (Nam 2007)}

Palisada crustiformans (McDermid) A.R.Sherwood, A.Kurihara \& K.W.Nam comb. nov. Fig. 4; Table 2

\section{Basionym}

Laurencia crustiformans McDermid, Phycologia 28: 352, figs 2-8 (McDermid 1989).

\section{Type material}

\section{Holotype}

USA: Hawaii, KM 2050 (BISH) (Abbott 1999: 384).

\section{Type locality}

Lualualei Beach Park, Oahu, Hawaii.

\section{Other material examined}

USA: Hawaii, Isaac Hale Beach Park, Hawaii Island, 24 Jan. 2008, A. Kurihara ARS03327/BISH 766726 (BISH).
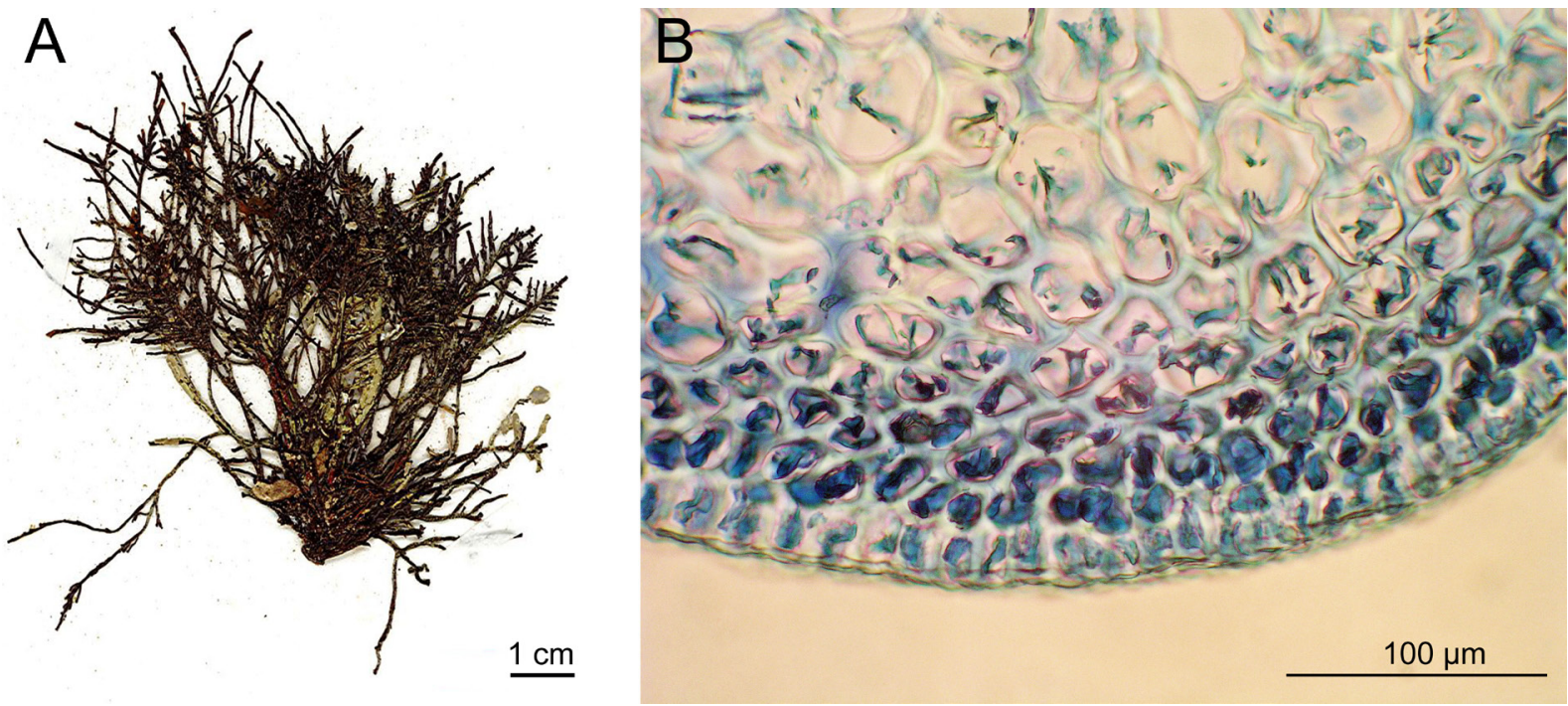

Fig. 3. Ohelopapa flexilis (Setch.). A. Voucher specimen (01A07/UPF4223) collected at Tahiti (type locality). B. Transversal section through outer cortex showing a translucent outermost cortical layer lacking secondary pit connections between cells. 


\section{Distribution}

Recorded from Hawaii and Tahiti.

\section{Remarks}

The Palisada crustiformans (Fig. 4) specimen included in this study was sterile and matched previous descriptions by McDermid (1989) concerning vegetative characters. In particular, secondary pit connections between cortical cells were observed (Fig. 4C). Small structures that may or may not be 'corps en cerise', were also observed in cortical cells (Fig. 4B-C).

Genus Osmundea Stackh. (Stackhouse 1809)

Osmundea caspica (Zinova \& Zaberzhinskaya) Maggs \& L.M.McIvor comb. nov.

Fig. 5; Table 2

\section{Basionym}

Laurencia caspica Zinova \& Zaberzhinskaya, Novosti Sistematiki Nizshikh Rastenii 1968: 30-32 (Zinova \& Zaberzhinskaja 1968).

\section{Type material}

AZERBAIJAN: Jun. 1962, K.M. Petrov, V.L. Komarov Botanical Institute (LE), Saint-Petersburg.

\section{Type locality}

Svinoy, Sangi-Mugan Island, Baku Archipelago, Caspian Sea, Azerbaijan.

\section{Other material examined}

AZERBAIJAN: Sangachal Bay, Sep. 2003, ERT Caspian Contractors BM001062596 (BM).

\section{Distribution}

Recorded from the Black Sea (Bulgaria and Romania) and Caspian Sea (Guiry \& Guiry 2016), both of which are low salinity bodies of water.

\section{Description}

The description of L. caspica is published in Russian in a book that is not widely available, so here we provide the following description.
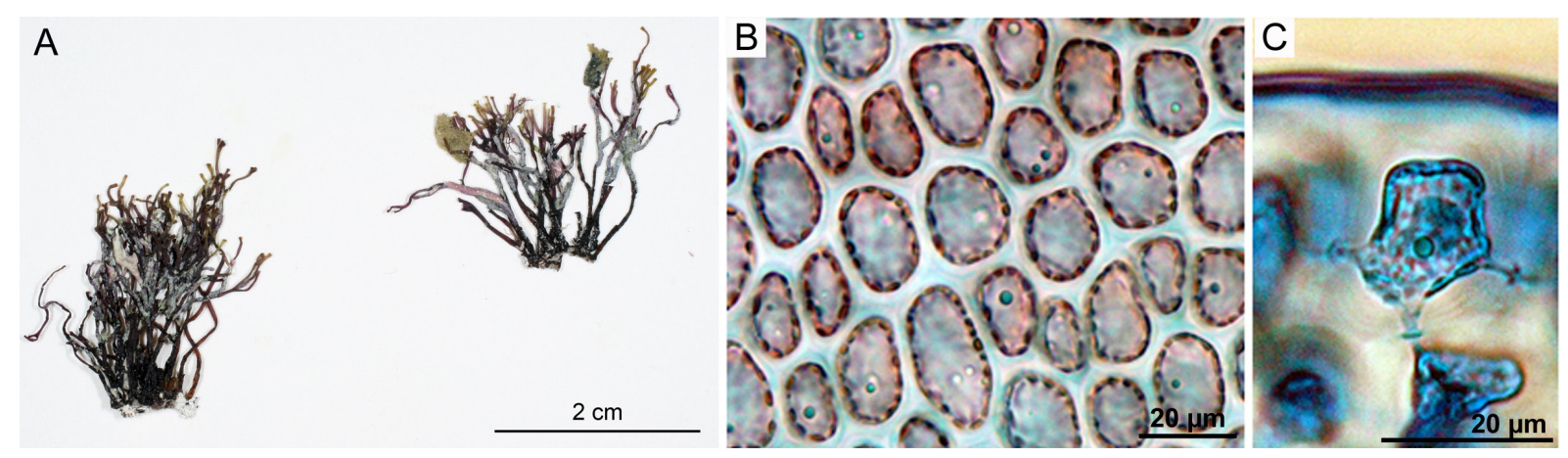

Fig. 4. Palisada crustiformans (McDermid). A. Voucher specimen of P. crustiformans (ARS03327/BISH 766726) collected at Hawaii Island (type locality). B. Outer cortical cells in surface view. C. Detail of outermost cortical cell showing small spherical structure similar to 'corps en cerise' and secondary pit connections with adjacent cells. 
Thalli were 5-11 cm high, growing from a solid discoid basal holdfast; erect axes terete, about $1 \mathrm{~mm}$ in diameter, irregularly branched to three orders, with blunt apices, similar in general habit to Laurencia obtusa with the exception of the holdfast (Fig. 5A). In surface view of the cortex of live thalli, there were no 'corps en cerise'; in surface view of preserved and stained cortical preparations, secondary pit connections were absent (Fig. 5B). In transverse section of axes, pericentral cells were not distinguishable, and the cortical cells were comparatively large and slightly radially elongated (Fig. 5C). Lenticular thickenings were absent in medullary cells.

Mature non-reproductive thalli, tetrasporophytes and males were collected but females are unknown. Tetrasporangia $80-110 \mu \mathrm{m}$ in diameter occurred in bands below the apices of lateral branches. They were produced adaxially from random epidermal cells, cut off laterally from the mother cells. Spermatangial receptacles were terminal and open cup-shaped. Spermatangial structures were of the filament type (Nam et al. 2000); spermatangial filaments were unbranched, bearing numerous elongate spermatangia, and terminating in single large round to ovoid cells up to $40 \mu \mathrm{m}$ in diameter (Fig. 5D-E).

\section{Discussion}

In the present study we focused on assessing the generic affinities of some species of Laurencia which displayed atypical characters for the genus Laurencia s. str.

Contrary to other Laurencia species, L. flexilis has neither secondary pit connections between cortical cells nor 'corps en cerise' but axial cells of its sterile branches have four pericentral cells like species of

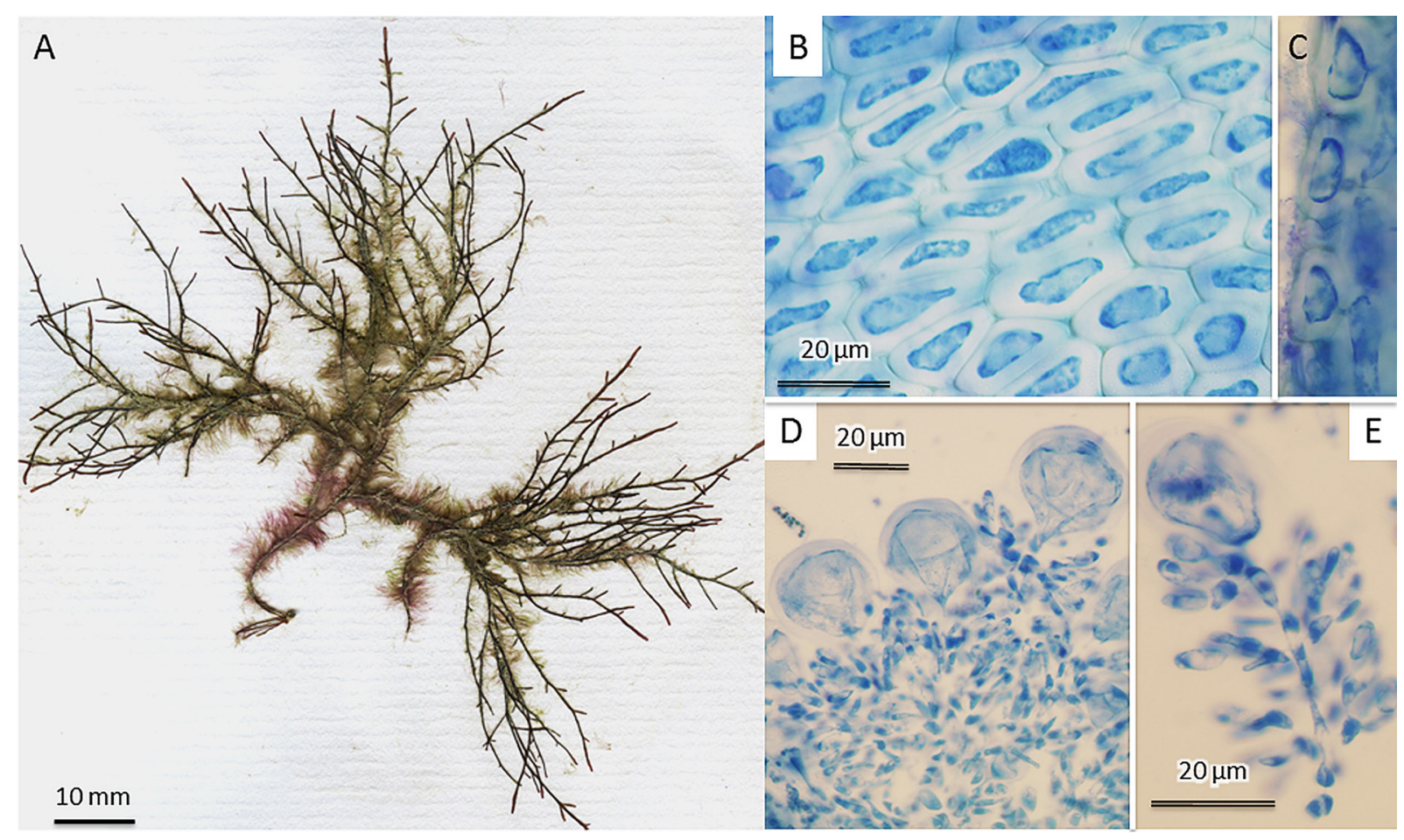

Fig. 5. Osmundea caspica (A.D.Zinova \& Zaberzhinskaya). Sangachal Bay, Azerbaijan, September 2003, dredged. A. Habit of herbarium voucher specimen with epiphytic acrochaetioid red algae. B. Outer cortical cells in surface view, elongated along the thallus axis, lacking secondary pit connections.

C. Longitudinal section through outer cortex (scale bar as in B). D. Part of mature spermatangial receptacle, showing spermatangial filaments each terminating in a large rounded sterile cell. E. Spermatangial filament bearing mature spermatia and terminating in a rounded sterile cell. 
Laurencia s. str. (Masuda et al. 1999, observed both in specimens from Malaysia and Setchell's original material from Tahiti preserved in SAP; Masuda et al. 2006, based on both Setchell's original material and Japanese specimens). In the molecular analyses of Abe et al. (2006), L. flexilis was resolved as an independent divergent lineage of Laurencia s. str. with no supported relationships with any other genera. In our analyses, we confirm that $L$. flexilis does not have strong affinities with any of the currently described genera of the Laurencia complex and we therefore propose here to accommodate L. flexilis in Ohelopapa gen. nov.

When Nam (2007) elevated Palisada to generic rank, he included a cladistic analysis based on the anatomical characters of Laurencia crustiformans and resolved it within a species group for which he proposed novel combinations to be accommodated in Palisada. Surprisingly, he did not propose the transfer of Laurencia crustiformans to Palisada. Given that our molecular phylogeny is congruent with his cladistic analysis, we here propose the new combination Palisada crustiformans.

Osmundea caspica was described from the Caspian Sea in 1968 as Laurencia caspica, previously identified as L. hybrida (DC.) T.Lestib. (now O. hybrida; see Zinova 1967). It lacks 'corps en cerise' and secondary pit connections between cortical cells, a couple of features shared by almost all the Laurencia s. str. species. Osmundea caspica is very similar to Osmundea maggsiana D.Serio, Cormaci \& G.Furnari from the Mediterranean in the anatomical features considered important in this genus, sharing a solid discoid holdfast, terete axes, lacking 'corps en cerise' and secondary pit connections in the cortex, lacking lenticular thickenings in the medulla, and having cup-shaped spermatangial receptacles with individual spermatangial filaments terminating in 1-2 large cells (Fig. 5; Serio et al. 1999; Furnari 2001). The main difference is that whereas $O$. caspica is up to $11 \mathrm{~cm}$ high, and the axes are less than $1 \mathrm{~mm}$ in diameter, $O$. maggsiana is smaller (up to $5.5 \mathrm{~cm}$ ) but more robust, up to $3 \mathrm{~mm}$ in diameter. Also, in $O$. maggsiana cortical cells are markedly radially elongated in longitudinal section ("palisadelike", Serio et al. 1999; Fig. 5), whereas in O. caspica cortical cells are isodiametric in longitudinal section (Fig. 5C). Osmundea maggsiana is apparently known only from a single collection from Pantelleria Island, Straits of Sicily (Serio et al. 1999), consisting of males and tetrasporophytes but no cystocarpic thalli. Osmundea caspica also resembles $O$. hybrida from the Atlantic, but the spermatangial filaments terminate in single cells rather than in groups of up to 20 large cells as in O. hybrida (Maggs \& Hommersand 1993). The spermatangial development on filaments terminated by large sterile cells and the origin of tetrasporangia from outer cortical cells observed in $O$. caspica are distinctive characters of the genus Osmundea.

Despite its evident morphological similarities with Osmundea, L. caspica has never been transferred to Osmundea. It is widespread and common in the Caspian Sea (Zinova 1967), and it has also been reported from the Black Sea (Gómez Garreta et al. 2001). It is the only species of Osmundea that occurs in low-salinity conditions, occurring in the Caspian at 12-13 PSU.

The disjunct distribution of Osmundea was considered by McIvor et al. (2002) to correspond to a late Tethyan distribution pattern: "the genus would likely have originated in the western Tethyan Ocean after effective closure of the Tethyan Seaway between $60 \mathrm{Ma}$ and $20 \mathrm{Ma}$ during Oligocene or Miocene." McIvor et al. (2002) noted the apparent absence of species of Osmundea in the tropical western Atlantic and Indo-West Pacific Oceans. The discovery of Osmundea in the Caspian Sea strengthens the hypothesis of a Tethyan origin. In the late Eocene (ca $37 \mathrm{Ma}$ ), the tropical Tethys Ocean vanished due to the northward movement of India (Scotese 2016). The western relic Tethys connected the Atlantic Ocean to the Indo-Pacific, and the Turgai Strait opened to the Polar Sea (Rögl 1998). The Caspian Sea is a remnant of the epicontinental Paratethys, a gulf of the original Tethys Ocean (van Baak et al. 2013; Scotese 2016), which was connected to the North Sea during the early Oligocene (ca $32 \mathrm{Ma}$ ) but then ca $30 \mathrm{Ma}$ the closure of open seaways isolated Paratethys, leaving its only marine connections to the 
Mediterranean in the west (Rögl 1998). Complete isolation of the Caspian and Black Seas occurred in the Miocene (ca $18 \mathrm{Ma}$ ) followed by a complex series of marine transgressions and interconnections during which the Mediterranean-Indian Ocean seaway finally closed ca $15 \mathrm{Ma}$, but the southern basins of the Caspian (1 km deep) never dried up (Rögl 1998; van Baak et al. 2013). The Caspian Sea contains ancient palaeoendemics such as the sturgeons (Osteichthyes: Acipenseridae; Choudhury \& Dick 1998). The phylogenetic position of O. caspica at the first divergence of the Osmundea group (Fig. 1) strongly supports a late Tethyan origin of the genus within the tropical Laurencieae. The phylogeny of Osmundea shows a deep divergence between the North East Atlantic [including Atlantic islands]-Mediterranean clade and an American clade (Fig. 1; Machín-Sánchez et al. 2016). McIvor et al. (2002) noted the apparent absence of species of Osmundea from the tropical western Atlantic in contrast to observations on Tethyan distributions (Hommersand 2007) that "More often than not related taxa also occur in the western Atlantic Ocean and Caribbean Sea". The discovery of two Osmundea species in SE Brazil (Osmundea sanctarum M.T.Fujii \& Rocha-Jorge from offshore islands of the State of São Paulo (RochaJorge et al. 2013) and Osmundea lata (M.Howe \& W.R.Taylor) Yonesh., M.T.Fujii, \& Gurgel from a depth of $60 \mathrm{~m}$ off Cabo Frio, State of Rio de Janeiro; Yoneshigue-Valentin et al. 2003) has now shown that the distribution of Osmundea is typically Tethyan. In addition, the known distribution of Osmundea sinicola (Setch. \& N.L.Gardner) K.W.Nam now includes Pacific Panama as well as the Galapagos Islands (Littler \& Littler 2010). The earliest diverging species in the American clade is O. sanctarum, which is further evidence that this clade originated by vicariance as the South Atlantic opened up ca 100 Ma in the Cretaceous (Scotese 2016), then spread to the NE Pacific and diversified (Fig. 6).

In addition to clarifying the generic affinities of some species so far known as Laurencia, this paper provides new records for the two recently described genera Laurenciella and Yuzurua. Laurenciella

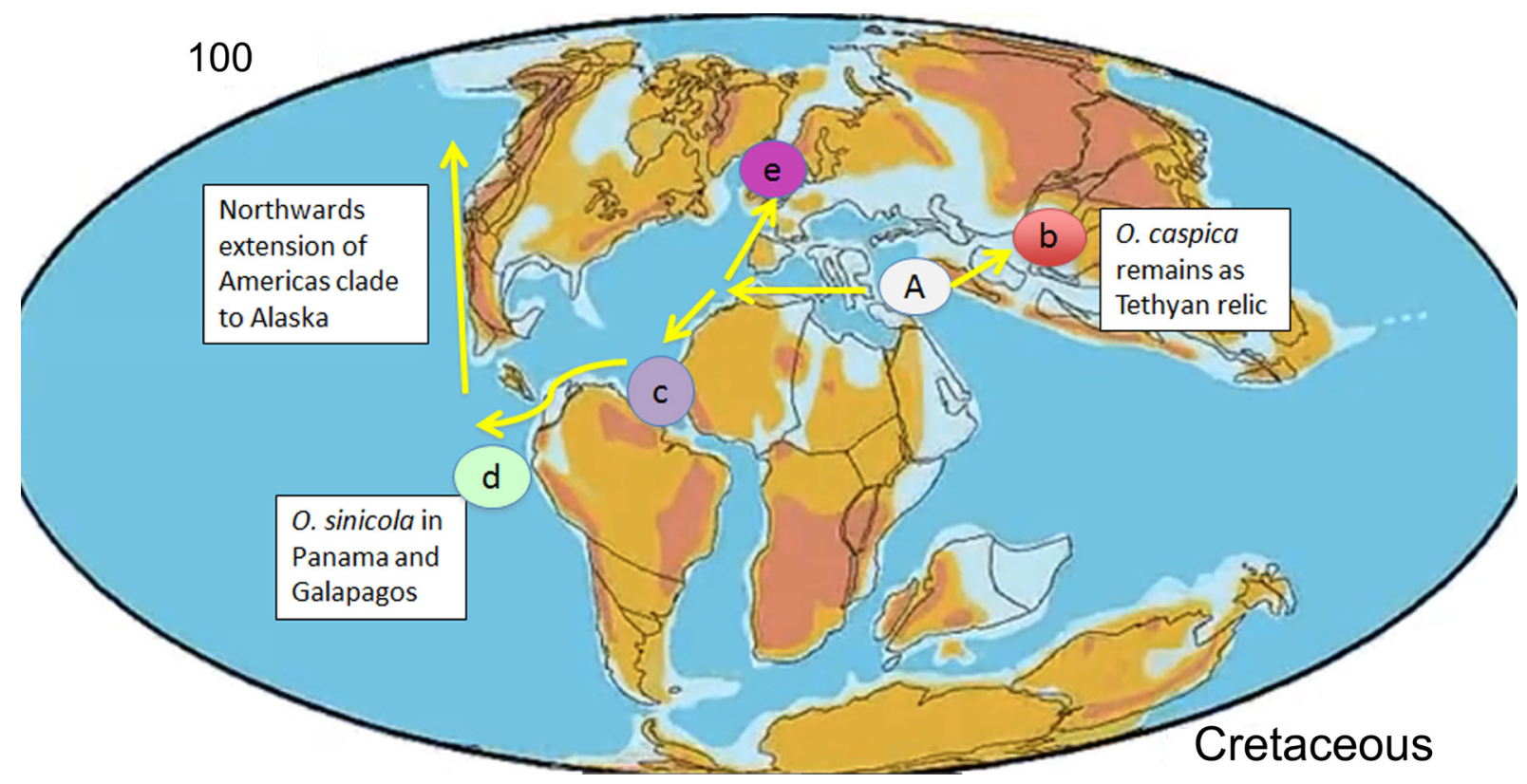

Fig. 6. Scenario of Osmundea biogeography using frame from Scotese animation (www.scotese.com/) at $100 \mathrm{Ma}$. South America and Africa are starting to move apart. Hypothetical ancestors (A) of widespread and diverse Osmundea flora along Tethyan shores of which Osmundea caspica (A.D.Zinova \& Zaberzhinskaya) comb. nov. (b) is almost certainly a relic. Since $100 \mathrm{Ma}$, Osmundea has colonized the Atlantic Ocean (c, e). Brazilian O. sanctarum M.T.Fujii \& Cord.-Mar. (c) is likely a relic of the lineage at the origin of the clade that entered the Pacific (d) and colonized the Americas. 
marilzae (Gil-Rodríguez, Sentíes, Díaz-Larrea, V.Cassano \& M.T.Fujii) Gil-Rodríguez, Sentíes, DíazLarrea, V.Cassano \& M.T.Fujii was initially described based on specimens from the Canary Islands of Macaronesia (Gil-Rodríguez et al. 2009) as a new species of Laurencia. When the new genus Laurenciella was described, L. marilzae was reported both in Brazil and in the Canary Islands. In 2014, the species was also reported in Mexico and in many islands of Macaronesia (Machín-Sánchez et al. 2014). Here, we further extend the distribution of the genus to the Mediterranean Sea; however, we question whether this new record is conspecific with $L$. marilzae as it falls in the grey zone between intra- and interspecific divergence $(0.5 \%$ of divergence in $r b c \mathrm{~L})$. Unfortunately, our specimens were pressed as herbarium vouchers, a technique which does not preserve tissues of members of the Laurencia complex well enough for a thorough anatomical study. The genus Yuzurua was proposed to accommodate L. poiteaui (J.V.Lamour) M.Howe, the type locality of which is Santo Domingo, Dominican Republic, based on molecular data for specimens from Mexico and USA (Martin-Lescanne et al. 2010). In the present study we report one specimen of Yuzurua from Guadeloupe which displays a divergence that clearly indicates that the two lineages are not conspecific (4.7\%). Further anatomical studies are needed to assess whether we need to describe a new species for this Guadeloupian record.

\section{Conclusion and perspectives}

This study, which is the first examination of the Laurencia complex based on both a taxon-rich dataset $(r b c \mathrm{~L})$ as well as a character-rich data set (combining COI-5P $+r b c \mathrm{~L}+\mathrm{LSU})$, has once again indicated that the Laurencia complex is more diverse than currently recognized at the generic level and has confirmed that molecular-assisted systematics constitutes a helpful tool to assign species of the notoriously difficult Laurencia complex to a genus. Despite the fact that the genera of the Laurencia complex are currently well delimited using molecular characters, relationships among them are still poorly resolved. More molecular data, as well as broader taxon sampling, are still necessary to further improve our understanding of this taxonomic complex in an evolutionary framework. Advances in next generation sequencing create novel opportunities to develop phylogenomic analyses. The recent publication of a plastid genome of a species of Laurencia (Verbruggen \& Costa 2015) paves the way toward plastome phylogenetic analyses of the Laurencia complex which will likely break the stranglehold of unresolved phylogenetic relationships.

\section{Acknowledgments}

The molecular data were produced at the Service de Systématique Moléculaire of the Muséum national d'Histoire naturelle (CNRS-UMS 2700) with funds provided by the ATM 'Taxonomie moléculaire: DNA Barcode et gestion durable des collections' and 'Emergence'. Sequencing was performed by Genoscope through the projects entitled 'Bibliothèque du Vivant'. The sequencing of Hawaiian specimens was funded by the U.S. National Science Foundation (DEB-0542608 to ARS and G.G. Presting) and was performed by the ASGPB Facility at the University of Hawaii. New Caledonian specimens were collected during the BSM-LOYAUTE campaign (http://dx.doi.org/10.17600/5100030) and BIODIP campaign (http://dx.doi.org/10.17600/5100100). We would like to thank our colleagues Olivier De Clerck, Eric Coppejans, André Pham, Heroen Verbruggen and Mike Wynne for providing specimens of the Laurencia complex, as well as Mayalen Zubia for the scan of the Ohelopapa flexilis herbarium plate and Yola Metti for providing us with the $r b c \mathrm{~L}$ sequences newly generated in Metti at al. 2015. CAM thanks Bill Boulton of Environment \& Resource Technology Limited Azerbaijan for providing live samples from the Caspian Sea, Ki Wan Nam for his comments on material of Osmundea caspica and Michael Guiry for information on the type specimen.

\section{References}

Abbott I.A.1999. Marine Red Algae of the Hawaiian Islands. Bishop Museum Press, Honolulu, Hawaii. 
Abe T., Kurihara A., Kawaguchi S., Terada R. \& Masuda M. 2006. Preliminary report on the molecular phylogeny of the Laurencia complex (Rhodomelaceae). Coastal Marine Science 30: 209-2013. Available from http://repository.dl.itc.u-tokyo.ac.jp/dspace/handle/2261/5634 [accessed 24 Nov. 2016].

Areschoug J.E. 1847. Phycearum, quae in maribus Scandinaviae crescunt, enumeratio. Sectio prior Fucaceas continens. Nova Acta Regiae Societatis Scientiarum Upsaliensis 13: 223-382.

Cassano V., Oliveira M.C., Gil-Rodríguez M.C., Sentíes A., Díaz-Larrea J. \& Fujii M.T. 2012. Molecular support for the establishment of the new genus Laurenciella within the Laurencia complex (Ceramiales, Rhodophyta). Botanica Marina 55: 349-357. http://dx.doi.org/10.1515/bot-2012-0133

Choudhury A. \& Dick T.A. 1998. The historical biogeography of sturgeons (Osteichthyes: Acipenseridae): a synthesis of phylogenetics, palaeontology and palaeogeography. Journal of Biogeography 25: 623640. http://dx.doi.org/10.1046/j.1365-2699.1998.2540623.x

Clayden S.L. \& Saunders G.W. 2014. A study of two Acrochaetium complexes in Canada with distinction of Rhododrewia gen. nov. (Acrochaetiales, Rhodophyta). Phycologia 53: 221-232. http:// dx.doi.org/10.2216/13-224.1

Cribb A.B. 1983. Marine Algae of the Southern Great Barrier Reef. Part I. Rhodophyta. Handbook no. 2. Australian Coral Reef Society, Brisbane.

Cronquist A. 1960. The divisions and classes of plants. The Botanical Review 26: 425-482. Available from http://www.jstor.org/stable/4353622 [accessed 24 Nov. 2016].

ERT Caspian 2002. Sangachal seabed mapping survey. Environment \& Resource Technology Limited, Azerbaijan. http://subsites.bp.com/caspian/ACG/Eng/esia1/ape08.pdf

Freshwater D.W. \& Rueness J. 1994. Phylogenetic relationships of some European Gelidium (Gelidiales, Rhodophyta) species, based on $r b c \mathrm{~L}$ nucleotide sequence analysis. Phycologia 33: 187-194. http:// dx.doi.org/10.2216/i0031-8884-33-3-187.1

Fujii M.T. \& Cordeiro-Marino M. 1996. Laurencia tanslucida sp. nov. (Ceramiales, Rhodophyta) from Brazil. Phycologia 35: 542-549. http://dx.doi.org/10.2216/10031-8884-35-6-542.1

Fujii M.T., Guimaràes S.M.P.B., Gurgel C.F.D. \& Fredericq S. 2006. Characterization and phylogenetic affinities of the red alga Chondrophycus flagelliferus (Rhodomelaceae, Ceramiales) from Brazil on the basis of morphological and molecular evidence. Phycologia 45 (4): 432-441. http://dx.doi. org/10.2216/04-33.1

Furnari G. 2001. The Laurencia complex (Rhodophyta, Rhodomelaceae) in the Mediterranean Sea: an overview. Cryptogamie, Algologie 22: 331-373. http://dx.doi.org/10.1016/S0181-1568(01)01065-0

Garbary D. \& Harper J. 1998. A phylogenetic analysis of the Laurencia complex (Rhodomelaceae) of the red algae. Cryptogamie, Algologie 19: 185-200.

Gil-Rodríguez M.C., Sentíes A., Díaz-Larrea J., Cassano V. \& Fujii M.T. 2009. Laurencia marilzae sp. nov. (Ceramiales, Rhodophyta) from the Canary Islands, Spain, based on morphological and molecular evidence. Journal of Phycology 45: 264-271. http://dx.doi.org/10.1111/j.1529-8817.2008.00624.x

Gómez Garreta A., Gallardo T., Ribera M.A., Cormaci M., Furnari G., Giaccone G. \& Boudouresque C.F. 2001. Checklist of Mediterranean Seaweeds. III. Rhodophyceae Rabenh. 1. Ceramiales Oltm. Botanica Marina 44: 425-460. http://dx.doi.org/10.1515/BOT.2001.051

Guiry M.D. \& Guiry G.M. 2016. AlgaeBase. World-wide electronic publication, National University of Ireland, Galway. Available from http://www.algaebase.org [accessed 20 Jan. 2016]. 
ROUSSEAU F. et al., Ohelopapa, a new genus of the Laurencia complex

Harper J.T. \& Saunders G.W. 2001. Molecular systematics of the Florideophyceae (Rhodophyta) using nuclear large and small subunit rDNA sequence data. Journal of Phycology 37: 1073-1082. http:// dx.doi.org/10.1046/j.1529-8817.2001.00160.x

Hommersand M.H. 2007. Global biogeography and relationships of the Australian marine macroalgae. In: McCarthy P.M. \& Orchard A.E. (eds) Algae of Australia: Introduction: 511-559. Australian Biological Resources Study, Canberra.

Lamouroux J.V.F. 1813. Essai sur les genres de la famille des thalassiophytes non articulées. Annales $d u$ Muséum d'Histoire Naturelle 20: 21-47, 115-139, 267-293, pls 7-13.

Le Gall L. \& Saunders G.W. 2010. DNA barcoding is a powerful tool to uncover algal diversity: a case study of the Phyllophoraceae (Gigartinales, Rhodophyta) in the Canadian flora. Journal of Phycology 46: 374-389. http://dx.doi.org/10.1111/j.1529-8817.2010.00807.x

Littler D.S. \& Littler M.M. 2010. Marine Plants of Pacific Panama. Smithsonian Tropical Research Institute, Smithsonian Institution, Washington D.C. (updated Jan. 2010). Available from http://biogeodb. stri.si.edu/pacificalgae [accessed 18 Nov. 2016].

Lüning K. 1990. Seaweeds, Their Environment, Biogeography and Ecophysiology. John Wiley \& Sons, New York.

Machín-Sánchez M., Le Gall L., Neto A.I., Rousseau F., Cassano V., Sentíes A., T. Fujii M.T., DíazLarrea J., Prud'homme van Reine W.F., Bonillo C. \& Gil-Rodríguez M.C. 2014. A combined barcode and morphological approach to the systematics and biogeography of Laurencia pyramidalis and Laurenciella marilzae (Rhodophyta). European Journal of Phycology 49: 115-127. http://dx.doi.org/1 $\underline{0.1080 / 09670262.2014 .893017}$

Machín-Sánchez M., Rousseau F., Le Gall L., Cassano V., Neto A.I., Sentíes A., Fujii M.T., Gil-Rodríguez M.C. 2016. Species diversity of the genus Osmundea (Ceramiales, Rhodophyta) in the Macaronesian region. Journal of Phycology 52 (4): 664-681. http://dx.doi.org/10.1111/jpy.12431

Maggs C.A. \& Hommersand M.H. 1993. Seaweeds of the British Isles. Volume 1. Rhodophyta. Part 3 A. Ceramiales. HMSO, London.

Martin-Lescanne J., Rousseau F., Reviers B. de, Payri C., Couloux A., Cruaud C. \& Le Gall L. 2010. Phylogenetic analyses of the Laurencia complex (Rhodomelaceae, Ceramiales) support recognition of five genera: Chondrophycus, Laurencia, Osmundea, Palisada and Yuzurua stat. nov. European Journal of Phycology 45: 51-61. http://dx.doi.org/10.1080/09670260903314292

Masuda M., Abe T., Kawaguchi S. \& Phang S.M. 1999. Taxonomic notes on marine algae from Malaysia I. Six species of Rhodophyceae. Botanica Marina 42: 449-458. http://dx.doi.org/10.1515/BOT.1999.052

Masuda M., Tani M. \& Kurihara A. 2006. New records of three marine red algae from Japan. Phycological Research 54: 244-254.

McDermid K.J. 1989. Laurencia crustiformans sp. nov. (Ceramiales, Rhodophyta) from the Hawaiian Islands. Phycologia 28: 352-359. http://dx.doi.org/10.2216/i0031-8884-28-3-352.1

McIvor L., Maggs C.A. Guiry M.D. \& Hommersand M.H. 2002. Phylogenetic analysis of the geographically disjunct genus Osmundea Stackhouse (Rhodomelaceae, Rhodophyta). Constancea. Available from http://ucjeps.berkeley.edu/constancea/ [accessed 18 Nov. 2016].

Metti Y., Millar A.J.K. \& Steinberg P. 2015. A new molecular phylogeny of the Laurencia complex (Rhodophyta, Rhodomelaceae) and a review of key morphological characters result in a new genus, Coronaphycus, and a description of C. novus. Journal of Phycology 51: 929-942. http://dx.doi. org/10.1111/jpy.12333 
Nam K.W. 1999. Morphology of Chondrophycus undulata and C. parvipapillata and its implications for the taxonomy of the Laurencia (Ceramiales, Rhodophyta) complex. European Journal of Phycology 34: 455-468. http://dx.doi.org/10.1080/09541449910001718811

Nam K.W. 2007. Validation of the generic name Palisada (Rhodomelaceae, Rhodophyta). Algae 22: 53-55.

Nam K.W. \& Choi H.G. 2000. A detailed morphological study of the type species of Osmundea (Rhodomelaceae, Rhodophyta). Botanica Marina 43: 291-297. http://dx.doi.org/10.1515/BOT.2000.031

Nam K.W., Maggs CA. \& Garbary D.J. 1994. Resurrection of the genus Osmundea with an emendation of the generic delineation of Laurencia (Ceramiales, Rhodophyta). Phycologia 33: 384-395.

Nam K.W., Maggs C.A., McIvor L. \& Stanhope M.J. 2000. Taxonomy and phylogeny of Osmundea (Rhodomelaceae, Rhodophyta) in Atlantic Europe. Journal of Phycology 36: 759-772. http://dx.doi. org/10.1046/j.1529-8817.2000.00013.x

Oltmanns F. 1904. Morphologie und Biologie der Algen. Vol. 1, Special Part. Gustav Fischer, Jena.

Rocha-Jorge R., Cassano V., Barros-Barreto M.B., Díaz-Larrea J., Sentíès A., Gil-Rodríguez M.C. \& Fujii M.T. 2013. Osmundea sanctarum sp. nov. (Ceramiales, Rhodophyta) from the southwestern Atlantic Ocean. Phytotaxa 100: 41-56. http://dx.doi.org/10.11646/phytotaxa.100.1.5

Rögl F. 1998. Paleogeographic considerations for Mediterranean and Paratethys seaways (Oligocene to Miocene). Annalen des Naturhistorischen Museums in Wien 99: 279-310.

Ronquist F., Teslenko M., van der Mark P., Ayres D.L., Darling A., Hohna S., Larget B., Liu L., Suchard M.A. \& Huelsenbeck J.P. 2012. MrBayes 3.2: Efficient Bayesian phylogenetic inference and model choice across a large model space. Systematic Biology 61: 539-542. http://dx.doi.org/10.1093/sysbio/ sys029

Saito Y. 1967. Studies on Japanese species of Laurencia, with special reference to their comparative morphology. Memoirs of the Faculty of Fisheries, Hokkaido University 15: 1-81.

Saunders G.W. 2005. Applying DNA barcoding to red macroalgae: a preliminary appraisal holds promise for future applications. Philosophical Transactions of the Royal Society B: Biological Sciences 360: 1879-1888. http://dx.doi.org/10.1098/rstb.2005.1719

Saunders G.W. \& Hommersand M.H. 2004. Assessing red algal supraordinal diversity and taxonomy in the context of contemporary systematic data. American Journal of Botany 91: 1494-1507. http://dx.doi. org/10.3732/ajb.91.10.1494

Scotese C.R. 2016. Paleomap project. Available from www.scotese.com/earth.htm [accessed 18 Nov. 2016].

Serio D., Cormaci M. \& Furnari G. 1999. Osmundea maggsiana sp. nov. (Ceramiales, Rhodophyta) from the Mediterranean Sea. Phycologia 38: 277-282. http://dx.doi.org/10.2216/i0031-8884-38-4-277.1

Setchell W.A. 1926. Tahitian algae collected by W.A. Setchell, C.B. Setchell and H.E. Parks. University of California Publications in Botany 12: 61-142.

Sherwood A.R., Kurihara A., Conklin K.Y., Sauvage T. \& Presting G.G. 2010a. The Hawaiian Rhodophyta Biodiversity Survey (2006-2010): a summary of principal findings. BMC Plant Biology 10: 258. http://dx.doi.org/10.1186/1471-2229-10-258

Sherwood A.R., Sauvage T., Kurihara A., Conklin K.Y. \& Presting G.G. 2010b. A comparative analysis of COI, LSU and UPA marker data for the Hawaiian florideophyte Rhodophyta: implications for DNA barcoding of red algae. Cryptogamie, Algologie 31: 451. 
Silva P.C., Basson P.W. \& Moe R.L. 1996. Catalogue of the Benthic Marine Algae of the Indian Ocean. University of California Press, Berkeley.

Stackhouse J. 1809. Tentamen marino-cryptogamicum, ordinem novum; in genera et species distributum, in Classe XXIVta Linnaei sistens. Mémoires de la Société Impériale des Naturalistes de Moscou 2: [50]-97.

Stamatakis A. 2014. RAxML version 8: a tool for phylogenetic analysis and post-analysis of large phylogenies. Bioinformatics 30: 1312-1313. http://dx.doi.org/10.1093/bioinformatics/btu033

Tamura K., Stecher G., Peterson D., Filipski A. \& Kumar S. 2013. MEGA6: Molecular Evolutionary Genetics Analysis Version 6.0. Molecular Biology and Evolution 30: 2725-2729. http://dx.doi. org $/ 10.1093 / \mathrm{molbev} / \mathrm{mst} 197$

Thiers B. Continuously updated. Index Herbariorum: A global directory of public herbaria and associated staff. New York Botanical Garden's Virtual Herbarium. Available from http://sweetgum.nybg.org/ science/ih/ [accessed 18 Nov. 2016].

Van Baak C.G.C., Vasiliev I., Stoica M., Kuiper K.F., Forte A.M., Aliyeva E. \& Krijgsman W. 2013. A magnetostratigraphic time frame for Plio-Pleistocene transgressions in the South Caspian Basin, Azerbaijan. Global and Planetary Change 103:119-134. http://dx.doi.org/10.1016/j. gloplacha.2012.05.004

Verbruggen H. \& Costa J.F. 2015. The plastid genome of the red alga Laurencia. Journal of Phycology 51: 586-589. http://dx.doi.org/10.1111/jpy.12297

Wettstein R. von 1901. Handbuch der Systematischen Botanik. Vol. 1. Franz Deuticke, Leipzig \& Vienna.

Yoneshigue-Valentin Y., Fujii M.T. \& Gurgel C.F.D. 2003. Osmundea lata (M. Howe \& W.R. Taylor) comb. nov. (Ceramiales, Rhodophyta) from the Brazilian south-eastern continental shelf. Phycologia 42: 301-307.

Zinova A.D. 1967. Opredelitel Zelenikh, Burikh i Krasnich Odoroslei Juzhnikh Morei SSSR [Guide to the Green, Brown and Red Algae of the Southern Seas of USSR]. Academia Nauka, Moscow \& Leningrad.

Zinova A.D. \& Zaberzhinskaja E.B. 1968. Species rhodophytorum Maris Caspici novae. Novosti Sistematiki Nizshikh Rastenii 1968: 28-33.

Manuscript received: 10 March 2016

Manuscript accepted: 27 June 2016

Published on: 2 February 2017

Guest editors: Line Le Gall, Frédéric Delsuc, Stéphane Hourdez, Guillaume Lecointre

and Jean-Yves Rasplus

Desk editor: Danny Eibye-Jacobsen

Printed versions of all papers are also deposited in the libraries of the institutes that are members of the EJT consortium: Muséum national d'Histoire naturelle, Paris, France; Botanic Garden Meise, Belgium; Royal Museum for Central Africa, Tervuren, Belgium; Natural History Museum, London, United Kingdom; Royal Belgian Institute of Natural Sciences, Brussels, Belgium; Natural History Museum of Denmark, Copenhagen, Denmark; Naturalis Biodiversity Center, Leiden, the Netherlands. 